\title{
The Availability and Uses of E-Resources in the College Libraries of Baksa District of Assam: Current Status and Prospects
}

\author{
Rajiv Kalita
}

\begin{abstract}
The present education system is moving from the traditional to towards the digital and electronic base environment. The dominance of the ICT has put an effective impact on the college libraries too. In the development index, the NE Region of India is always lacking behind, which may be due to its socio-economic, geographical and demographical conditions. Hence, in the educational sector has always a tremendous pressure to overcome such barriers.

The educational resources available with the academic institutions play a key role in uplifting the quality and overall development of the students at a large. Therefore, this study try to portrait an actual picture of the current E-resources available in the college libraries of Baksa district of Assam and as well as, it will try to figure out the availability and uses of those resources by the library users through some findings.
\end{abstract}

Index Terms: ICT, E-resources, college library, Baksa district

\section{INTRODUCTION}

The information technology has already influenced every field of our modern life. The mass developments in the computer science and its networking technologies have drastically changed the whole communication scenario. These technological advancements have changed the patterns of the whole world at a large and also transform the teaching learning process from the traditional physical environment to the virtual or digital platform.

The higher education is a powerful tool to build knowledge-base society in the new era and hence have a vital importance in the country. And in this connection, the academic libraries basically the college libraries become the backbone of the mass learning community.

Updating and upgrading the library resources are always an important task for the academic library system. In this connection, the introduction and implementation of the new technologies always been treated as a potential means to increasing the quality of the library services and also to improving the efficiency of the operations. E-resources are also the result of such new technology which mainly deals with the digital objects containing the electronic representation of the reading materials which can easily be accessed through a computer $24 \mathrm{X} 7$.

It is seemed that the existing college library system is trying their level best to compete with the new generation. Although, the new trends in the ICT are pulling them to change and

Revised Manuscript Received on July 09, 2019.

Rajiv Kalita, Librarian-cum-Research Officer, Gauhati High Court, Itanagar Permanent Bench, Naharlagun, Arunachal Pradesh. accept the new changes in the ongoing educational system. The colleges of the urban areas are gearing up to meet the current demands. In the urban area's colleges, there is no problem to applications of the computers and E-resources in their libraries. But in the developing districts like Baksa of Assam, despite of their short of available resources are also trying to deliver the adequate and latest information to their users.

\section{AN OVERVIEW OF THE BAKSA DISTRICT}

By the signed of the landmark BTC (Bodoland Territorial Council) accord on 10/02/2003, the BTAD (Bodoland territorial Autonomous District) was formed in Assam. In the BTAD, 4(four) numbers of districts namely Kokrajhar, Chirang, Baksa and Udalguri are bifurcated from the various existing surrounded districts. Baksa district with approx. $2400 \mathrm{Sq} \mathrm{Km}$ of geographical area had carved out from the parts of Nalbari, Barpeta, Kamrup and a small part of the Darrang district.

There is a mass controversy over the originality of the word 'Baksa'. It is still a matter of controversy whether the word 'Baksa' is originated from the word 'Bagsa' or 'Bangsa' as huge fractions of people used to believe in each to be the originated one.

The Baksa district is located in the North-Western part of Assam sharing its international boundary with Bhutan and its other domestic boundaries with districts of Assam like Udalguri, Darrang, Kamrup, Nalbari, Barpeta and Chirang. The district headquarter i.e. at Mushalpur is about $105 \mathrm{Km}$ away from the state capital of Assam. The Baksa district is a pure example of a mix community inhabited like Bodo-Kachari, Assamese, Koch-Rajbongshi, Sarania-Kachari, Nepali-Gorkhas, Adibashi, Bengali and other religious minorities in its 9.5377 lakhs of population as per 2011 census.

\section{HIGHER EDUCATION IN BAKSA DISTRICT OF ASSAM}

The Baska district of Assam may rightly be called as a developing district of the State, emphasizing to boost up every sector. Although, like many others, the education sector is a prominent area of challenge to upgrade. According to the 2011 census, the total literacy rate of Baksa district is $69.25 \%$ (Male- $77.03 \%$ and Female- 61.27\%) which 
is less than that of the average literacy rate of the state i.e. $72.19 \%$.

Apart from the various Govt. and Private educational institutions at different levels, the 5(five) provincialised colleges are disseminating the higher education in the district since the 1970's. The provincialised colleges in this district i.e. Barama College at Barama, Goreswar College at Goreswar, B.B. Kishan College at Jalahghat, Salbari College at Salbari and Gyanpeeth Degree College at Nikashi are the prominent manufacturers of the quality human resources from this locality. These colleges are affiliated to the Gauhati University, Guwahati having a good number of enrolments in the Bachelor and even PG levels. Simultaneously, these colleges are also functioning as the study centres for the K.K. Handique State Open University and IDOL, GU offering various courses.

\section{Methodology}

This study is conducted mainly on the basis of the primary data, collected from the provincialised college libraries situated in the district of Baksa, Assam. In this connection, a questionnaire was prepared and circulated among the college library professionals for collecting the data. Beside this, various websites and reference books relating to the Baksa district, higher education, E-resources etc. were being used in the study. Furthermore, semi structured interviews with the library professionals and observational visits in the libraries are also made to collect and analyze the data.

\section{OBJECTIVES OF THE STUdY}

The present study intends to cover the full range of facets of the availability and uses of the E-resources in the provincialised college libraries of the entire Baksa district of Assam. The specific objectives of the study are as follows-

1. To assess the current actual scenario of the availability and use of E-resources in the rural college libraries as like those of the Baksa district of Assam and also to study about the infrastructure for ICT in these libraries.

2. To compare the availability and use of the E-resources among the provincialised college libraries in Baksa district.

3. To discover the strength and weakness of the libraries to develop a good E-resource collection and dissemination system among its users.

4. To find out the need and importance of the E-resources in the libraries.

5. To suggest suitable measures to be adopted and elements of improvement for creating the ICT based collection availability and uses in the college libraries.

6. This study also aims to investigate the extent of adoption of ICT in the college libraries and its overall impact at a large and so on.

\section{SCOPE OF The STUdY}

As the study is confined within the Baksa district, hence it is tried to cover up all the provincialised colleges situated in the district. The provincialised college libraries selected for this study are-

1. Barama College at Barama.

2. Goreswar College at Goreswar.

3. B.B. Kishan College at Jalahghat.

4. Salbari College at Salbari.

5. Gyanpeeth Degree College at Nikashi.

\section{E-RESOURCES-AS DEFINED AND ITS IMPACT IN THE HIGHER EDUCATION SYSTEM}

Since long back, traditionally the college libraries have been acquiring the printed materials. However, giving emphasize to the information technology, now a days the libraries are also equally subscribing the E-resources for their use. Due to the more up-to-date, easy accessibility and crossing all the barriers, the E-resources are becoming very much important as well as popular in the current age.

The 'E-resources' refer to those materials which are stored electronically and can be accessed through electronic system and networks. Any electronic product that delivers a collection of data be it in text referring it to full text databases, electronic journals, image collections, other multimedia products, etc. they may be delivered on CD-ROM, Pen Drive, Hard drive, via internet and so on are termed as E-resources. E-resources are the synonym to the digital resources, online resources, internet resources etc.

According to the AACR, an E-resource is "Material (data and/or program(s)) encoded from manipulation by a computerise device. This material may require the use of a peripheral directly connected to a computerized device or a connection to a computer network."

IFLA defines E-resources as "to those materials that require computer access, whether through a personal computer, mainframe, or handheld mobile device. They may either be accessed remotely via Internet or locally" (IFLA, 2012)

The world is moving rapidly towards the digital media and information. For which, the role and impact of the E-resources in the higher education system is becoming more and more important. Simultaneously, in the last few decades the higher education system has grown up exponentially where the E-resources have became an inseparable part of the system. To make the higher education system more productive and efficient the E-resources hold a great potential. The E-resources have not only a prominent role to play in supporting the higher education but also to fulfil the educational objectives.

The Govt. of India had established the University Grants Commission (UGC) in the year 1956 with an intention to uplift and assist mainly the higher education system of the country. From the very day of the establishment the UGC has also trying its level best to maintain the quality of the higher education throughout the country and also to produce the best human resources for the nation. Since 1987 , the UGC has been assisting the

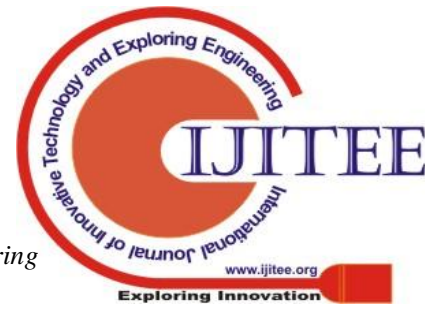


colleges for procuring computers so as to create the awareness among the staff and the students and also to upgrade themselves with the need of the time.

In the state of Assam there are cluster of courses in the field of higher education. In these regard, in every district the educational institutions are providing various traditional as well as vocational and technical courses to its student communities. Apart from that, the research communities are also taking help from these academic libraries to boost their research works. Hence, to meet the ongoing demand of the user community, the library can't fully depend upon the traditional printed materials and to provide the current and latest information in a flexible mode of dissemination have to relay upon the E-resources which become the call of the present time.

\section{ANALYSIS OF THE PRIMARY DATA}

Depending upon the data collected from the five provincialised college libraries of the Baksa district of Assam the following content tables are prepared and accordingly analysed the available data in a systematic manner.

Table 1: Details of college libraries as surveyed

\begin{tabular}{|c|c|c|c|c|c|c|}
\hline Name of the college & Name of the library & $\begin{array}{c}\text { Year of } \\
\text { establishment }\end{array}$ & $\begin{array}{c}\text { Total } \\
\text { collection }\end{array}$ & $\begin{array}{c}\text { Total } \\
\text { numbers of } \\
\text { users }\end{array}$ & $\begin{array}{c}\text { Number of } \\
\text { professional } \\
\text { staff }\end{array}$ & $\begin{array}{c}\text { Number of } \\
\text { supporting } \\
\text { staff } \\
\end{array}$ \\
\hline Barama College & Surendra Nath Das Library & 1971 & 37954 & 2100 & 1 (vacant) & 3 \\
\hline Goreswar College & Goreswar College Library & 1974 & 40000 & 2200 & 1 (vacant) & 3 \\
\hline B.B. Kishan College & B.B.Kishan College Library & 1978 & 19000 & 1450 & 1 & 2 \\
\hline Salbari College & Salbari College Library & 1983 & 13338 & 1100 & 1 (vacant) & 3 \\
\hline Gyanpeeth Degree College & Late Prasanna Sarma Memorial Library & 1993 & 13000 & 1200 & 1 (vacant) & 3 \\
\hline
\end{tabular}

From the collected data, it is observed that although these college libraries were established since 1970's but at present $80 \%$ of the total college libraries are functioning without a proper library head i.e, a librarian. In this situation the libraries which are having a good number of users and also with a healthy traditional collection have to run and look after by the semi or non professional staffs which is also insufficient in quantity.

\section{Table 2: Users dependency}

\begin{tabular}{|c|c|c|c|c|c|}
\hline & $\begin{array}{c}\text { Barama } \\
\text { College }\end{array}$ & $\begin{array}{c}\text { Goreswar } \\
\text { College }\end{array}$ & $\begin{array}{c}\text { B.B. Kishan } \\
\text { College }\end{array}$ & $\begin{array}{c}\text { Salbari } \\
\text { College }\end{array}$ & $\begin{array}{c}\text { Gyanpeeth } \\
\text { Degree College }\end{array}$ \\
\hline $\begin{array}{c}\text { Traditional } \\
\text { resources }\end{array}$ & YES & YES & YES & YES & YES \\
\hline E-resources & NO & NO & NO & NO & NO \\
\hline
\end{tabular}

As the data received from the college libraries, it is seemed that the authorities as well as the user community are still fully depending on the traditional printed materials or documents for their day to day study. They are even mostly unaware about the availability and vast benefits about the E-resources or E-study materials.

Table 3: Distribution of libraries having Internet connectivity and library management software

\begin{tabular}{|l|l|l|l|l|l|}
\hline & Barama College & $\begin{array}{l}\text { Goreswar } \\
\text { College }\end{array}$ & $\begin{array}{l}\text { B.B. Kishan } \\
\text { College }\end{array}$ & Salbari College & $\begin{array}{l}\text { Gyanpeeth } \\
\text { Degree College }\end{array}$ \\
\hline $\begin{array}{l}\text { Internet } \\
\text { connectivity }\end{array}$ & YES & NO & NO & YES & NO \\
\hline Library software & YES & NO & YES & YES & NO \\
\hline
\end{tabular}

From the study it is found that only $40 \%$ of the total college libraries are having the internet connectivity in its library premises. Besides these, $60 \%$ of the libraries are currently using the library management software i.e, 'SOUL'

although it is at an infant stage till date and functioning partially only. Besides these, $40 \%$ of the libraries are still outside the preview of any library management software.

Table 4: Barriers for collection development applying the ICT application

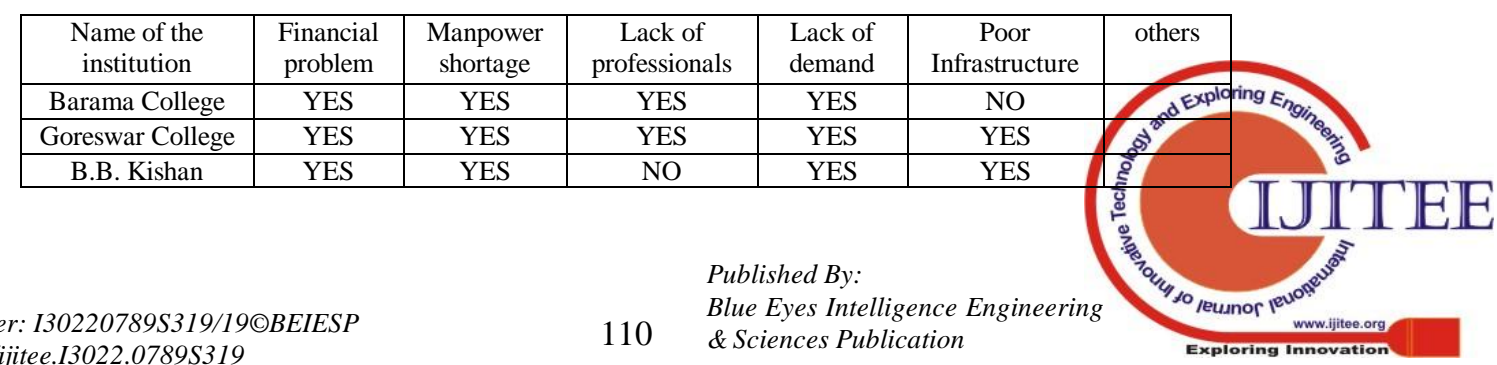


The availability and uses of E-resources in the college libraries of Baksa district of Assam: Current status and prospects

\begin{tabular}{|c|l|l|l|l|l|l|}
\hline College & & & & & & \\
\hline Salbari College & YES & YES & YES & YES & NO & \\
\hline $\begin{array}{c}\text { Gyanpeeth } \\
\text { Degree College }\end{array}$ & YES & YES & YES & YES & YES & \\
\hline
\end{tabular}

Finance is always a major barrier in up-gradation of library. Here in also all the libraries clearly sate about the finance to be the major factor in implementing the ICT based facilities. Besides these, engagements of proper manpower become one of the major issues to maximum of these libraries. Along with these, creating awareness and the demand for the E-resources among the users will be the key factor in these libraries. As from the study, it is found that still there is not any major demand from the user community for the E-resources. $60 \%$ of the libraries are also stressing on the poor infrastructure in the libraries and demands for it.

\section{Table 5: Internet connectivity}

\begin{tabular}{|c|c|c|c|}
\hline College & $\begin{array}{c}\text { Service } \\
\text { provider }\end{array}$ & Networking & $\begin{array}{c}\text { Computer } \\
\text { Nodes }\end{array}$ \\
\hline Barama College & JIO & WI-FI & 01 \\
\hline Goreswar College & NIL & NIL & NIL \\
\hline $\begin{array}{c}\text { B.B. Kishan } \\
\text { College }\end{array}$ & NIL & NIL & NIL \\
\hline Salbari College & JIO & WI-FI & 01 \\
\hline $\begin{array}{c}\text { Gyanpeeth Degree } \\
\text { College }\end{array}$ & NIL & NIL & NIL \\
\hline
\end{tabular}

Only $40 \%$ of the college libraries have been providing internet access facilities within the library premise. Most of the libraries do not have internet connectivity within the library premises. It is also found that the numbers of computer terminals are very less and also those having are not fully equipped or upto the mark.

It is found from the study that only a single college library provides access to E-resources through N-List Programme. All the libraries do not have any acquisition policy to procure the E-resources till date. Two out of the five college libraries have internet connectivity within the library premises through JIO Wi-Fi service with a limited access facility till date. It is also found from the study that the security and computer illiteracy are still the main problems faced by all the college libraries.

Going through the study, it is found that the scenario of the availability and use of the E-resources in the college libraries of Baksa district is very pathetic. Not a single college library is having any number of E-resources. Although, they have initiated for library management through 'SOUL' (library management software) which is still at an infant stage.

\section{RESUltS AND FINDINGS}

From the study some suggestions can be provided to enhance the accessibility of E-resources in these college libraries-

1. Engagement of the proper library professional at an urgent basis.

2. Libraries should think about acquiring the E-resources and for that there should be a clear provision in the library budget. Even a separate head may create to procure the E-resources for the library at a periodical manner.

3. Libraries should take initiatives to access E-resources available through N-List programme or from other free and open platforms.

4. Librarians should take comprehensive efforts to create awareness among the library users towards the benefits of E-resources and their uses.

4. Librarian should take special attention to make aware about the free resources available on web.

5. Librarian should take responsibility to teach the users how to pick information through Net/web.

6. Proper implementation for fast internet connectivity vide LAN or Wi-Fi system in the campus.

\section{Conclusion}

In the Baksa district of Assam, the second generation is taking education at a large. The socio-economic conditions of the people are not very sound, but the new generation is very much enthusiastic to pursue the education and even higher research activities. The colleges of these localities are also trying their level best to update and upgrade the educational need. Besides the financial support from the Govt., the provincialised colleges are also getting grants from the UGC under various schemes. Though the grants are limited in respect of the whole college, but still than the authorities and management of these colleges are trying to acquire the required materials for its users.

Due to the advanced technology, the world has become a global village and the youth are reaching to the upcoming modern world. The study achieved its aim of providing an updated summary of the current state of the art use of E-resources in the college libraries in the Baksa district. In the study it is found that the college libraries of this district have a negligible E-resource with them and hence the resources and the services are not reaching the user to the extent. The state of affairs has been largely due to the vacancy in the librarian post, inadequate finance, inadequate electronic recourses and inadequately trained library professionals. To overcome this unfortunate situations, the library/college management need to review their policies on library. They need to give priority to fill up the vacant posts at the library and also to deploy adequate numbers of staffs in the library. Giving emphasises to current need and demand, the management instead of heavily depending upon the traditional recourses, should have to set an adequate E-resources stock in their hand. The study may conclude that almost all the college libraries of the Baksa district need an urgent and proper inclusion of E-resources to

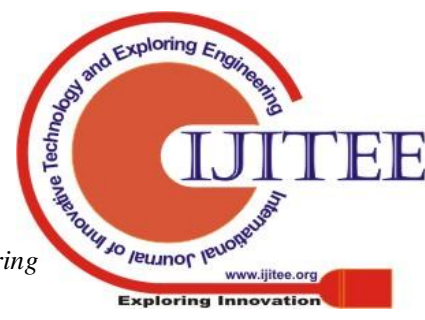


their library collections and simultaneously, the library staffs has to be engaged and trained properly to make the use of these resources optimally.

\section{REFERENCES}

1. Libraries. 5th International CALIBER-2007.Punjab University Chandighar.

2. Chakravarty,R \& Singh,S.(2005). E-resources for Indian Universities: New Initiatives. SRELS journal of Information Management.42(1),pp57-73

3. http://www.INFLIBNET.ac.in

4. https://www.census2011.co.in

5. http://baksa.gov.in/ 